\title{
Cytogenetic studies of Acute Myeloid Leukemia
}

\author{
Tarek Abd -Alla Atia \\ Histology Dept. Faculty of Medicine, Al-Azhar University, Cairo
}

\begin{abstract}
Acute myeloid leukemia (AML) describes as a group of hematopoietic stem cell disorders characterized by expansion of undifferentiated myeloid progenitors. Acquired chromosomal anomaly particularly reciprocal translocations constitute one of the major events contribute to leukemogenesis.
\end{abstract}

\section{Patient and Methods:}

45 untreated, newly diagnosed patients with de novo AML were enrolled in the present study and subjected to cytogenetic analysis. Four $\mathrm{ml}$ of heparinized peripheral blood were collected for 72 hours synchronized culture, and then chromosome G- banding analysis was performed using standard methods. The karyotypes were designated according to the International System for Human Cytogenetic Nomenclature (ISCN). The collected data were analyzed statistically.

\section{Result:}

Cytogenetic analysis and karyotype results were obtained in 45 patients with de novo AML. Males constituted $33.3 \%$, and females constituted $66.7 \%$ of this group. The patients' age ranged from 17-60 years. Chromosomal anomalies have been detected in 21 out of 45 patients (46.7\%). However five different types of chromosome anomalies have been detected; where seven cases (33.3\%) carrying $\mathrm{t}(15 ; 17)$ ( q22; 21$)$; six cases $(28.5 \%)$ carrying $\mathrm{t}(8 ; 21)(\mathrm{q} 22 ; \mathrm{q} 22)$; three cases $(14.3 \%)$ had trisomy 8 ; three cases $(14.3 \%)$ had monosomy 7 ; and lastly two cases $(9.5 \%)$ carrying inv(3)(q21q26).

\section{Conclusion:}

Conventional cytogenetic analysis reliability detects chromosomal abnormalities in AML patients at the time of diagnosis. Chromosomal anomalies detected in Egyptian AML patients, are similar to some extent to those recorded in other areas of the world.

Key words: cytogenetic, myeloid leukemia, karyotypes , trisomy, monosomy

\section{Introduction:}

Acute myeloid leukemia (AML) represents a hematopoietic malignancy characterized by abnormal cell proliferation and stalled differentiation leading to the accumulation of immature cells in bone marrow, in peripheral blood and eventually in other tissues (Schlenk, et al., 2008). AML are greatly variable in clinical course and response to therapy as well as in the genetic and molecular basis of their pathology (Mrozek \& Bloomfield, 2006).

The FAB (French-American-British) doctors have classified AML into subtypes (M0 through M7) based on the predominant line of differentiation, and the cell maturity.
FAB classification has limited prognostic value, whereas certain recurrent chromosomal abnormalities, prior to drug exposure and a history of a myelodysplastic syndrome are predictive of outcome (Kumar et al., 2007). One the other hand, the world health organization (WHO) classification of AML incorporates clinical, morphologic, immunophenotypic and genetic features in an attempt to define entities that are biologically homogeneous and have clinical relevance. The classification encompasses four major categories; AML with recurrent genetic abnormalities, AML with multilineage dysplasia, AML that is therapy related and 
AML not otherwise categorized (Schnittger et al., 2005).

At the cytogenetic level, clonal chromosome aberrations are identified in approximately $50 \%$ of all patients with de novo adult acute myeloid leukemia (Akagi et al., 2009). These chromosomal abnormalities provide important insights into the genes involved in the pathogenesis of leukemia. Clinically, chromosome aberrations are one of the most important prognostic factors in AML. This prognostic information is increasingly being used for treatment decisions, eg, whether a patient is assigned to an intense therapy such as bone marrow or blood stem-cell transplantation or to a less intense regimen. The remaining half of the patients lacks microscopically visible chromosome aberrations. For this clinically heterogeneous group of patients, prognostic markers are warranted for establishing risk-adapted therapy (Do"hner, et al. 2000).

Chromosome translocations constitute large proportion of the chromosomal anomalies, while other rearrangements i.e inversions, deletions occur in less than 3\%of cases (Godley, 2009). Frohling et al. (2002) has reported that in most cases of AML, conventional cytogenetic study reliably detects chromosomal abnormalities and this method should not be replaced by fluorescent in situ hybridization (FISH). FISH should be used as a complementary method for the detection of more subtle abnormalities. Furthermore, molecular

\section{Patient and Methods:}

45 patients; diagnosed as de novo AML, with no previous treatment, were subjected to this study. Patients have been collected, with formal consent, from the following sites: Clinical Pathology Department, Sews Canal University, Kasr El-Einy Center of Radiation, Oncology and Nuclear Medicine, Cairo University and Clinical Hematology Unit in El Maady Military Hospital, Cairo - Egypt cytogenetic using this comprehensive set of DNA probes provides a valuable diagnostic tool for patients with poor chromosome morphology, low or no yields of metaphase cells. Cytogenetic aberrations have been recognized as the most important prognostic variable in AML. In recent years, there has been growing interest in moving beyond cytogenetic to subsets of AML with molecular aberrations (i.e., mutated or abnormally expressed genes) that can be used for further stratification of AML patients (Renneville et al., 2008).

On the other hand, AML with no chromosomal abnormalities that are detected by conventional karyotyping and FISH techniques, are classified as AML not otherwise categorized. This patient group falls into the intermediate prognostic group, but individual patients can have substantially different clinical courses. Identification of prognostic markers suitable for further subdivision of this group will help to optimize their treatment. Molecular analysis has yielded novel gene mutations that serve as markers important for prognostic stratification of this group of AM (Löwenberg, 2008).

Major advances in the understanding of leukemogenesis have been made by the characterization and the study of acquired cytogenetic abnormalities particularly reciprocal translocations, as well as some gene mutations observed in AML (Renneville et al., 2008).

\section{Methods:}

- Data collection:

Patient personal data, the results of hematological examinations (complete blood count; hemoglobin level, white cell count (WBCs), platelets count, peripheral blast cells), immunophenotyping of myeloid cells by flow cytometry (CD13/DR, CD14, CD15, CD33, CD34, CD64), and the cytochemical analysis of the WBCs have been collected. 
- Cytogenetic analysis

Four $\mathrm{ml}$ of heparinized peripheral blood were collected for 72 hours synchronized culture, and then chromosome G- banding analysis was performed using standard methods. The karyotypes were designated according to the International System for Human Cytogenetic Nomenclature (ISCN) (Mitelman, 1995). The collected data were analyzed statistically.

\section{Result:}

Cytogenetic analysis and karyotype results were obtained in 45 patients. However, our study population revealed that 24 patients of $45(53.3 \%)$ had normal karyotypes and
21 patients of 45 (46.7\%) had abnormal karyotypes. Males constituted $33.3 \%$ of this group and females constituted $66.7 \%$. Patients' age ranged from 17-60 years. Age and sex distribution of our studied population with normal karyotype are shown in (table 1).

However, five different types of chromosomal abnormalities among the 21 cases have been detected; and are classified as follow: seven cases (33.3\%) carrying $\mathrm{t}(15 ; 17)(\mathrm{q} 22 ; \mathrm{q} 21)$ (figure 1); six cases $(28.5 \%)$ carrying $\mathrm{t}(8 ; 21)(\mathrm{q} 22 ; \mathrm{q} 22)$ (figure $2)$; three cases $(14.3 \%)$ had trisomy 8 (figure 3); three cases (14.3\%) had monosomy 7 (figure 4); and lastly two cases $(9.5 \%)$ carrying $\operatorname{inv}(3)(\mathrm{q} 21 ; \mathrm{q} 26)$ (figure 5).

\begin{tabular}{|l|l|c|c|}
\hline \multicolumn{2}{|c|}{} & Number & Percentage \\
\hline \multirow{3}{*}{ Sex } & Male & 8 & $38.1 \%$ \\
\cline { 2 - 4 } & Female & 13 & $61.9 \%$ \\
\hline \multirow{3}{*}{ Age } & Mean \pm SD & \multicolumn{2}{|c|}{$36.21 \pm 12.4$} \\
\cline { 2 - 4 } & Range & \multicolumn{2}{|c|}{$17-60$} \\
\hline
\end{tabular}

Table 1: Distribution of sex and age in patients with $A M L-N K(n=24)$. 


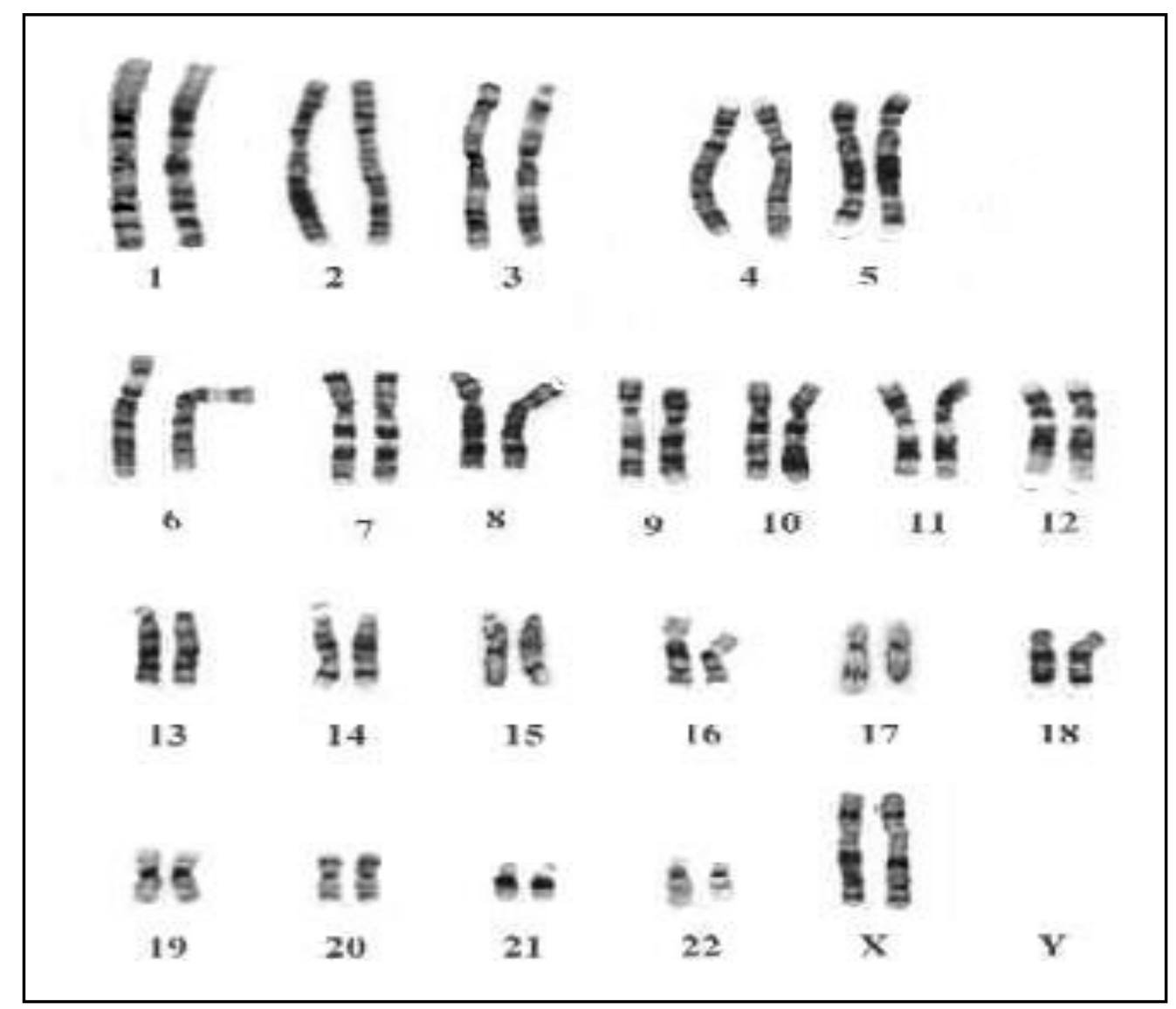

(Fig. 1): 46,XX,t(15;17)( q22;q21)

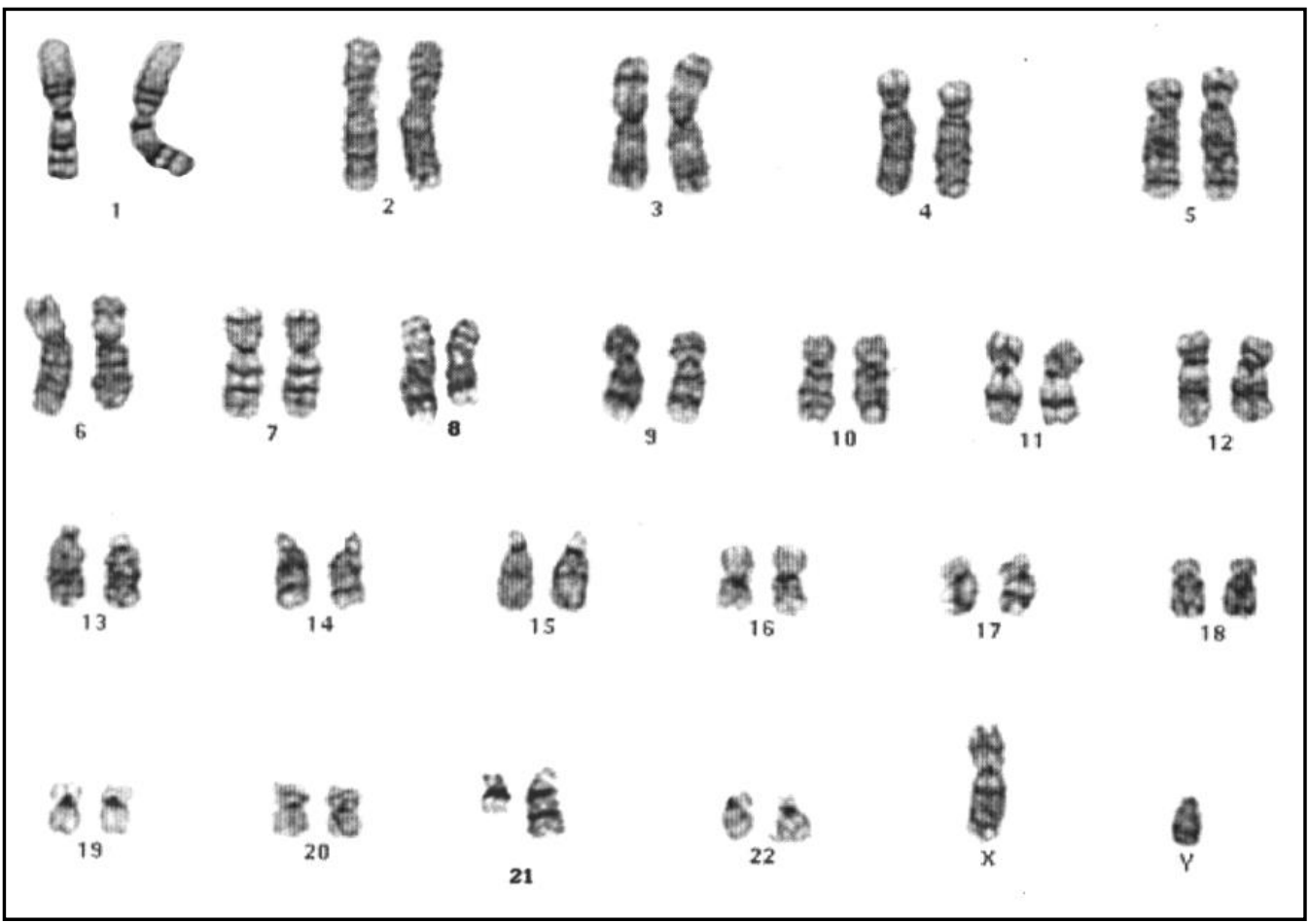

(Fig. 2): 46,XY,t(8;21)(q22;q22) 

Cytogenetic studies of....

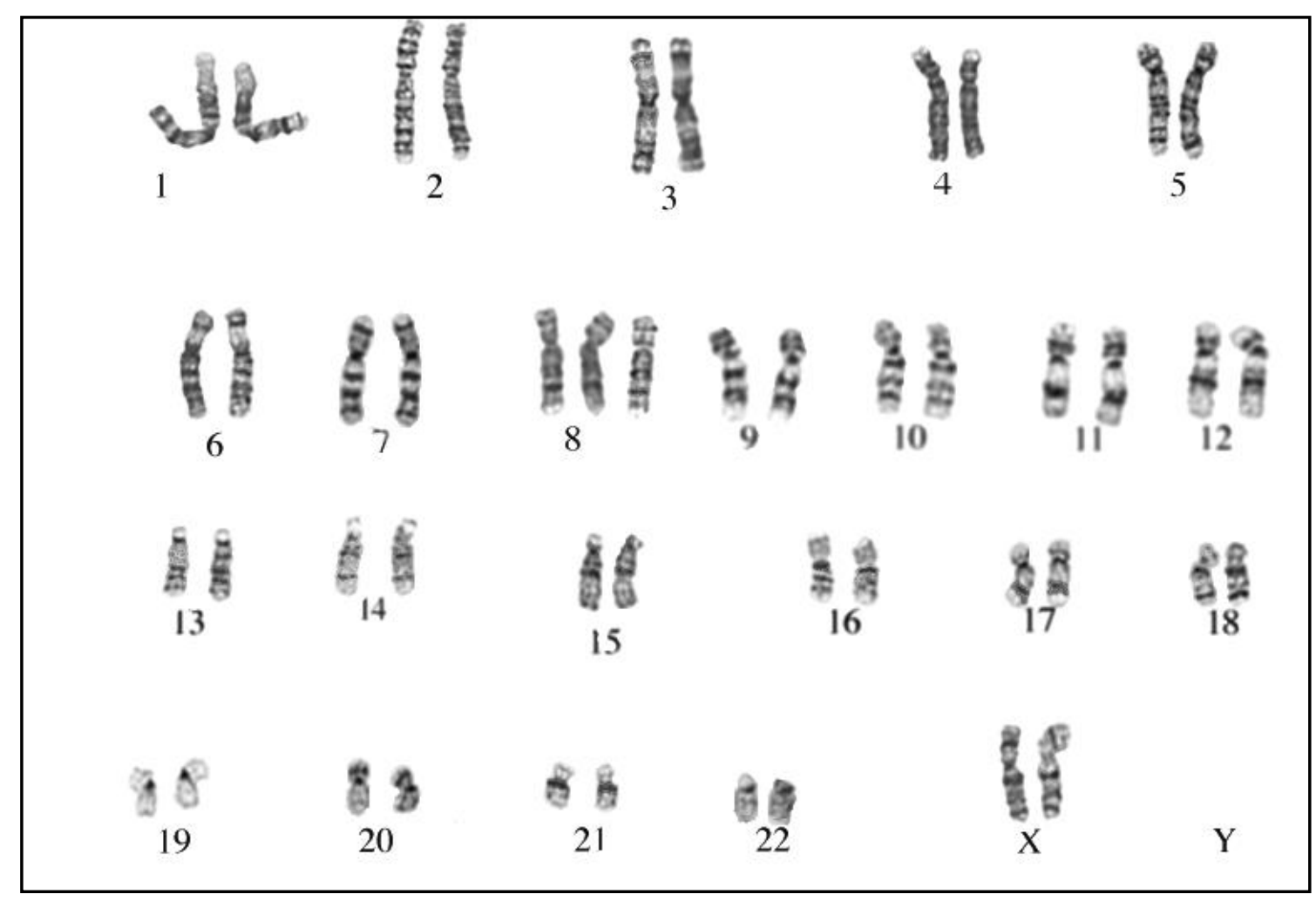

(Fig. 3): $47, X X,+8$

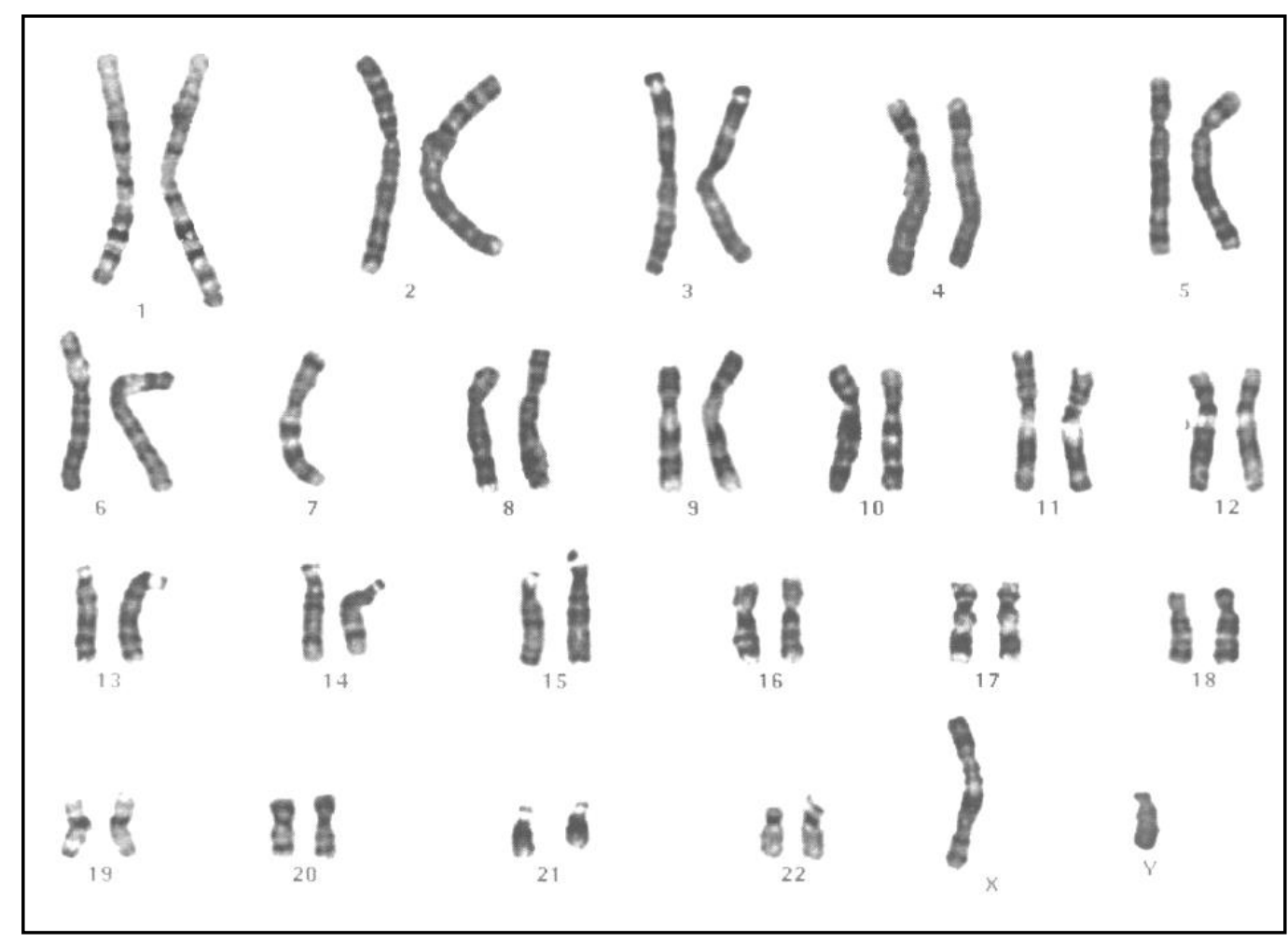

(Fig. 4): 45,XY,-7 



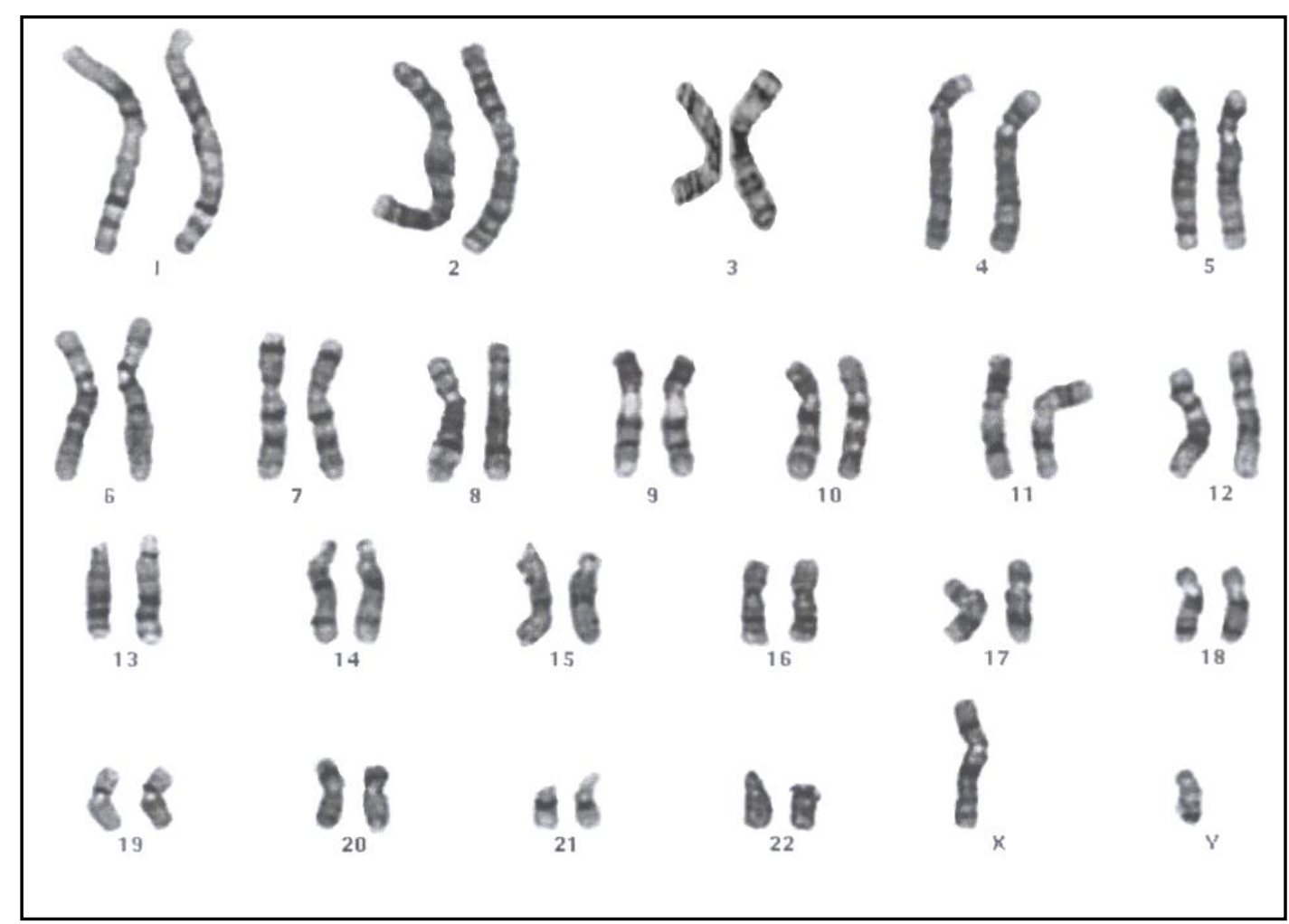

(Fig. 5): 46,XY,inv(3)(q21;q26)

\section{Discussion:}

Acute myelogenous leukemia represents a hematopoietic malignancy characterized by abnormal cell proliferation and stalled differentiation leading to the accumulation of immature cells in the marrow itself, in peripheral blood and eventually in other tissues. Karyotype is generally an important prognostic factor in AML; a favorable prognosis being associated with minor karyotypic changes, low frequency of abnormal bone marrow cells and changes specifically involving the $C B F \square$ gene. While a poor prognosis is associated with a monosomy 5 , monosomy 7 , trisomy 8 , abnormalities in the $3 \mathrm{q}$ and changes specifically involving the $M L L$ gene. Atypical cytogenetic findings have been sporadically reported in AMLM4 but the scarcity of these abnormalities poses a challenge of using such changes as prognostic factors, reinforcing the need for the collection of clinical data on rare events
(Strout et al., 1999; Chen and Sandberg, 2002).

Primary chromosomal abnormalities in AML are highly specific and considered to be associated with leukemic transformation, whereas secondary changes are less specific and probably contribute to disease progression. The common chromosomal abnormalities that have been recognized in the acute myelomonocytic leukemia include monosomy 5 or del(5q), monosomy 7 or $\operatorname{del}(7 \mathrm{q})$, trisomy 8 , $\mathrm{t}(6 ; 9)(\mathrm{p} 23 ; \mathrm{q} 34)$, and rearrangements involving the Mixed Lineage Leukemia (MLL) gene mapped at $11 \mathrm{q} 23 \quad$ [del(11)(q23); t(9;11)(p22;q23), $\mathrm{t}(11 ; 19)(\mathrm{q} 23 ; \mathrm{p} 13)]$, and Core Binding Factor B (CBF) mapped at 16q22 [del(16)(q22), $\quad \operatorname{inv(16)(p13q22),~}$ $\mathrm{t}(16 ; 16)(\mathrm{p} 13 ; \mathrm{q} 22)]$. Less frequently, trisomy 4 , trisomy $22, \mathrm{t}(8 ; 21)(\mathrm{q} 22 ; \mathrm{q} 22)$ and rearrangements with breakpoints in $3 \mathrm{q} 21$, $3 \mathrm{q} 26,8 \mathrm{p} 11,11 \mathrm{p} 15$ and $11 \mathrm{q} 13$ have also been reported in FAB type M4 patients (Fett-Conte et al, 2007). 
Our chromosomal analysis result showed that $53.3 \%$ of patients had normal karyotype. However, great variation have been detected in other studies; where, Garzon et al. (2007) has detected 50\%, but Alcalay et al. (2005) has detected $89.6 \%$, and lastly Frohling et al. (2005) has detected $45 \%$ of cases in their studies with normal karyotype. The discrepancy between the different results could be due to difference in the study population number, and/or due to geographical gene variation among normal population.

The prevalence of chromosomal abnormalities was estimated as $46.7 \%$ in the rest of patients. Translocation $(15 ; 17)$ has been frequently observed $(33.3 \%)$ in our results; that in turn is more or less similar to the result that was observed by . Gutiérrez-Angulo et al. (2004) among AML patients in his pilot study. Translocation $(15 ; 17)$ results in fusion of parts of the PML gene on chromosome $15 \mathrm{q} 22$ and the RARA gene on chromosome 17q12. The resulting fusion protein blocks differentiation at the promyelocyte stage. According to the two hit model hypothesis of leukemogenesis, $t(15 ; 17)$ is one of class 2 mutations which blocks differentiation. Mrozek and Bloomfield (2006) have reported that all AML patients with $\mathrm{t}(15 ; 17)(\mathrm{q} 22 ; 12-21)$ have excellent prognosis.

On the other hand, $t(8 ; 21)$ translocat the AML1 gene on chromosome 21 and fused it to the ETO gene on chromosome 8, results in an AL1-ETO fusion protein which in turn will inhibit the expression of $\mathrm{CBF}$ target genes resulting in blockage of myeloid differentiation. So that, $\mathrm{t}(8 ; 21)$ can consider as one of the class 2 mutations involved in leukemogenesis. Additionally, trisomy 8 is frequently seen with AML. Association between trisomy 8 and leukemia may be due to higher expression of ETO gene due to increased copies of chromosome 8 (Gutiérrez-Angulo et al., 2004).

\section{References:}

1. Akagi T, Shih LY, Ogawa S, Gerss J, Moore SR, Schreck R, Kawamata N, Liang DC, Sanada M, Nannya Y, Deneberg S, Zachariadis V, Nordgren A, Song JH, Dugas M, Lehmann S, Koeffler HP. (2009). Single nucleotide polymorphism genomic arrays analysis of $\mathrm{t}(8 ; 21)$ acute myeloid leukemia cells. Haematologica;94(9):1301-6.

2. Alcalay M, Tiacci E, Bergomas R, Bigerna B, Venturini E, Minardi SP, Meani N, Diverio D, Bernard L, Tizzoni L, Volorio S, Luzi L, Colombo E, Lo Coco F, Mecucci C, Falini B, Pelicci PG.(2005). Acute myeloid leukemia bearing cytoplasmic nucleophosmin (NPMc+ AML) shows a distinct gene expression profile characterized by up-regulation of genes involved in stem-cell maintenance. Blood; 106(3):899-902.

3. Chen $\mathrm{Z}$ and Sandberg AA (2002). Molecular cytogenetic aspects of hematological malignacies: Clinical implications. Am J Med Genet 115:130-141.

4. Döhner K, Schlenk RF, van der Reijden BA, Döhner H.(2000). Deletion of the multidrug resistance-associated protein (MRP1) gene in acute myeloid leukemia with inversion of chromosome 16 has no prognostic impact. Leukemia;14(6):1154.

5. Fett-Conte AC, Estrela RV, VendrameGoloni CB, Carvalho-Salles AB, Ricci-Júnior O and Marileila Varella-Garcia5 M. (2007). Atypical chromosome abnormalities in acute myeloid leukemia type M4. Genetics and Molecular Biology, 30, 1, 6-9

6. Fröhling S, Skelin S, Liebisch C, Scholl C, Schlenk RF, Döhner H, Döhner K; (2002). Comparison of cytogenetic and molecular cytogenetic detection of chromosome abnormalities in 240 consecutive adult patients with acute myeloid leukemia. J Clin Oncol. 15;20(10):2480-5.

7. Fröhling S, Kayser S, Mayer C, Miller S, Wieland C, Skelin S, Schlenk RF, Döhner H, Döhner K.(2005). Diagnostic value of fluorescence in situ hybridization for the detection of genomic aberrations in older patients with acute myeloid leukemia. Haematologica. $\quad ; 90(2): 194-9$. 
8. Garzon R, Pichiorri F, Palumbo T, Visentini M, Aqeilan R, Cimmino A, Wang H, Sun H, Volinia S, Alder H, Calin GA, Liu CG, Andreeff M, Croce CM.(2007). MicroRNA gene expression during retinoic acid-induced differentiation of human acute promyelocytic leukemia. Oncogene.;14;26(28):4148-57.

9. Godley LA.(2009). Deletion of the der(9q) in chronic myeloid leukemia: the controversy continues. Leuk Lymphoma;50(6):871-2.

10. Gutiérrez-Angulo M, González-García JR, Meza-Espinoza JP, Picos-Cárdenas V J, Esparza-Flores MA, López-Guido B, Rivera H. (2004). Increased expression of AML1-and acquired chromosomal abnormalities in childhood acute lymphoblastic Leukemia. Hematological Oncology; 22( 3): 85-90

11. Kumar P, Jain P, Menon H, Purvish P.(2007). Chronic myeloid leukemia presenting as paraneoplastic ocular myasthenia gravis. Ann Oncol.;18(4):804-5.

12.Löwenberg B. (2008). Acute Myeloid Leukemia: The Challenge of Capturing Disease Variety. Hematology: 1-11

13. Mitelman F (1995). ISCN: An International System for Human Cytogenetic Nomenclature. Basel, Switzerland, Karger.
14. Mrózek K, Bloomfield CD (2006). Chromosome aberrations, gene mutations and expression changes, and prognosis in adult acute myeloid leukemia. Hematology Am Soc Hematol Educ Program:169-77.

15. Renneville A, Roumier C, Biggio V, Nibourel O, Boissel N, Fenaux P, Preudhomme C.(2008). Cooperating gene mutations in acute myeloid leukemia: a review of the literature. Leukemia; 22(5):915-31.

16. Schlenk RF, Dhner K, Krauter J, Frehling S, Corbacioglu A, Bullinger L, Habdank M, Daniela Spath D, Morgan M, Benner A, Schlegelberger B, Heil G, Ganser A, and Dehner H. (2008). Mutations and Treatment Outcome in Cytogenetically Normal Acute Myeloid Leukemia. N Engl J Med 358;18

17. Schnittger S, Schoch C, Kern W, Mecucci C, Tschulik C, Martelli MF, Haferlach T, Hiddemann W, Falini B.(2005). Nucleophosmin gene mutations are predictors of favorable prognosis in acute myelogenous leukemia with a normal karyotype. Blood;106(12):3733-9.

18. Strout MP, Marcucci G, Caligiuri MA, Bloomfield CD. (1999). Core-binding factor (CBF) and MLL-associated primary acute myeloid leukemia: biology and clinical implications. Ann Hematol;78(6):251-64. 


\section{طارق عبد الله عطيه}

\section{قسم الهستولوجياـ كلية الطب-جامعة ـالازهر- القاهرة}

تعد سرطانات الدم الميلودية الحادة مجموعة من اضطر ابات الخلايا الجزعية لمكونات الدم والتي

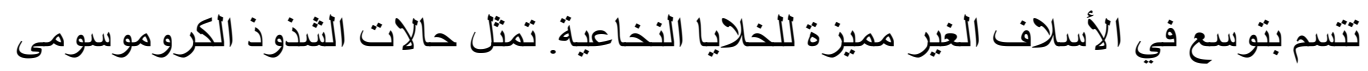

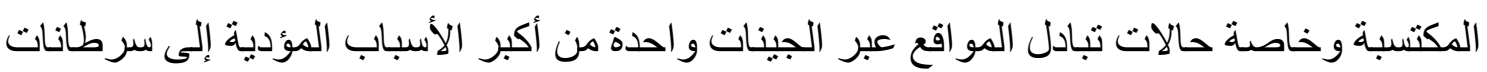

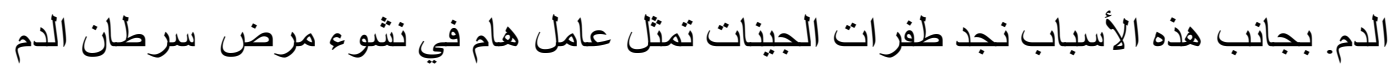

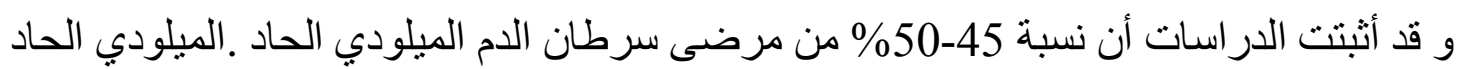
لم يكتشف لديهم شذوذ كروموسومى.

المرضى و طرق العمل: - مان مريضا بسرطان الدم الميلودي (ممن لم يسبق علاجهم)، تم سحب 45قد أجريت هذه الدراسة على

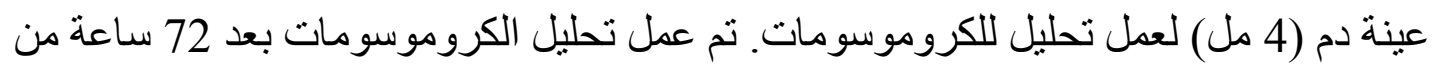
زر اعة الخلايا, وتم تحليل النتائج احصائيا

النتائج:

تم الحصول على التحليل الكروموسومى من زر اعة خلايا الدم لخمس و أربعين مريضا. أسفرت

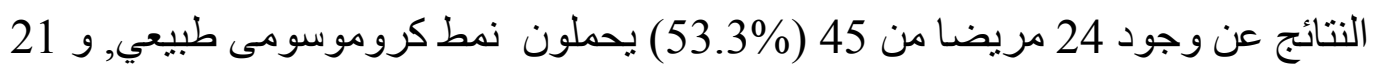
مريضا من 45 (46.7\%) يحملون شذوذ النمط الكروموسومى، حيث تم اكتشاف 5 أنواع لثنذوذ

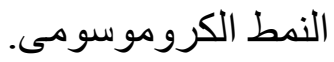

الاستنتاج:

نستخلص من هذه الدر اسة أن الوسائل التقليدية لدر اسة الكروموسومات توضح أنماط الثذوذ الكروموسومى في حالات سرطان الدم الميلودي الحاد. 